\title{
Removing Harvest Residues from Hardwood Stands Affects Tree Growth, Wood Density and Stem Wood Nutrient Concentration in European Beech (Fagus Sylvatica) and Oak (Quercus spp.)
}

\section{Sanjoy Roy ( $\square$ sanjoyroyku@yahoo.com )}

INRAE Centre Grand-Est Nancy: Institut National de Recherche pour l'Agriculture l'Alimentation et I'Environnement Centre Grand-Est Nancy https://orcid.org/0000-0003-4365-674X

\section{Jean-Michel Leban}

INRAE Centre Grand-Est Nancy: Institut National de Recherche pour I'Agriculture l'Alimentation et I'Environnement Centre Grand-Est Nancy

\section{Bernd Zeller}

INRAE Centre Grand-Est Nancy: Institut National de Recherche pour I'Agriculture l'Alimentation et I'Environnement Centre Grand-Est Nancy

\section{Gregory Van-Der-Heijden}

INRAE Centre Grand-Est Nancy: Institut National de Recherche pour I'Agriculture l'Alimentation et I'Environnement Centre Grand-Est Nancy

\section{Arnaud Reichard}

INRAE Centre Grand-Est Nancy: Institut National de Recherche pour l'Agriculture l'Alimentation et I'Environnement Centre Grand-Est Nancy

\section{Marie-Christine Gehin}

INRAE Centre Grand-Est Nancy: Institut National de Recherche pour l'Agriculture l'Alimentation et I'Environnement Centre Grand-Est Nancy

\section{Philippe Santenois}

INRAE Centre Grand-Est Nancy: Institut National de Recherche pour I'Agriculture l'Alimentation et I'Environnement Centre Grand-Est Nancy

\section{Laurent Saint-Andre}

INRAE Centre Grand-Est Nancy: Institut National de Recherche pour l'Agriculture l'Alimentation et I'Environnement Centre Grand-Est Nancy

\section{Research Article}

Keywords: harvest residues, Fagus silvatica, Quercus petraea, dendroecology, dendrochemistry, radial growth, wood density, tree growth, ring width, translocation 
Posted Date: August 24th, 2021

DOl: https://doi.org/10.21203/rs.3.rs-814871/v1

License: (c) (i) This work is licensed under a Creative Commons Attribution 4.0 International License. Read Full License

Version of Record: A version of this preprint was published at Forest Ecosystems on December 1st, 2022. See the published version at https://doi.org/10.1016/j.fecs.2022.100014. 


\section{Abstract}

Background: Increased exportation of harvest residues from forests, to mitigate excessive demand for woody biomass, have reportedly diminished soil mineral resources and may lead to degraded tree nutrition and tree growth. However, as nutrients become less available in the soil, the remobilization of nutrients in biomass tissues (plant internal cycling) helps sustain tree nutrition. Our study aims to quantify the impact of Removing Harvest Residues and Litter (RHRL) during five years on tree growth, wood density and stem wood nutrient concentrations in young beech and oak forest stands.

Result: Our study found that, RHRL significantly decreased the tree growth ring width, by $14 \%$, and wood density, by $3 \%$, in beech trees, in the near bark rings. RHRL also significantly reduced the nutrient concentration in the near bark and near pith area of both species. $\mathrm{Mg}, \mathrm{Na}$ and $\mathrm{S}$ were found lower by $44 \%$, $76 \%$ and $56 \%$, respectively, in the near bark area of beech trees, and $\mathrm{K}, \mathrm{Ca}, \mathrm{Mg}, \mathrm{Na}, \mathrm{S}$ and Fe were lower by $20 \%, 25 \%, 41 \%, 48 \%, 41 \%$ and $16 \%$, respectively, in the near bark area of oak trees. $\mathrm{K}$ and $\mathrm{Mg}$ concentrations decreased more strongly in the near pith area compared to the near bark area suggesting internal translocation of these two elements.

Conclusion: In beech trees, wood density proved to be an important factor while quantifying the effect of removing harvest residuals on the tree growth and biomass. Soil nutrient loss intensified the remobilization of nutrients contained in older tree rings (close to the pith) towards newly formed rings (close to bark). In our study, in beech trees, $\mathrm{K}$ was found to be the most recycled major nutrient. These results demonstrate the potential of such analysis for providing valuable insight into the effect of RHRL in premature stands on the physiological adaptive strategies of trees and an indication of soil fertility and acidity status.

\section{Background}

Removing harvest or logging residues from the forest has been promoted as a supplementary bioenergy source in Europe and around the world, derived from the response to alleviate anthropogenic pressure on fossil fuel consumption, to mitigate climate change effects, and to increase the contribution of renewable bio-resources to the energy mix. The EU policy for renewable energy, established in the EU Energy and Climate Change Package (CCP) and the Fuel Quality Directive (FQD), has promoted renewable energy, with a mandatory binding target of $20 \%$ in the overall energy mix of the EU by the end of 2020 and at least $32 \%$ by the end of 2030 (Phillips et al., 2018). However, there has been ongoing controversies concerning this strategy, because a substantial amount of recent and previous research has indicated that removing harvest residues from forest can affect ecosystem functioning and forest productivity (e.g., Conifers- Helmisaari et al., 2011; Kaarakka et al., 2014; hardwood species-Vanguelova et al., 2010; Wall, 2012; Tamminen et al., 2012; Hume et al., 2018; Maillard et al., 2019) by reducing nutrient availability in the soil (see metanalysis from- Thiffault et al., 2011; Achat et al., 2015a; Egnell, 2017; Clarke et al., 2021)). Most studies have observed effects of removing harvest residues on tree diameter and/or height and/or volume growth. However, to our knowledge no study has yet considered wood density as a contributing 
factor explaining the effect of removing harvest residues on tree biomass despite wood density being an equally important variable to translate tree volume into biomass. Due to highly associated costs of measurements, biomass estimates in practice rely on combining tree volume data with an average density value per species (IPCC, 2006), but different ecological factors such as water and nutrient availability, site elevation may strongly contribute to explaining variation of the inter and intra-specific wood density values (Castro et al., 2020; Kerfriden et al., 2021). Studies have indicated that the availability of soil nutrients affects the width of tree growth rings (e.g., Sheppard et al., 2001; Ponton et al., 2019). A sharp decline of soil nutrients was found to reduce diameter growth in hardwood species (Kint et al., 2012). Yet, little is known about the effect of nutrient availability on tree wood density. However, such findings can be important, not only to understanding the relationship between tree growth and wood density and its contribution to wood carbon estimation (Kerfriden et al., 2021) in both conifer and hardwood species, but also because wood density is an important parameter to produce desired quality timber, with higher mechanical properties (Saranpää, 2003).

The pools of nutrients accumulated in aboveground biomass are crucial to maintain tree physiology, vitality, and growth. Trees absorb most of their required nutrients in the soil and distribute them to the different tree organs through the xylem sapflow. Soil being the main reserve of nutrients for trees, a scarcity in soil mineral pool, is expected to engender reduction of nutrient contents in the plant woody tissues. However, previous studies have shown that (i) part of nutrient cations ( $\mathrm{Mg}$, $\mathrm{Ca}$ and $\mathrm{K}$ ) in biomass tissues are stored in an adsorbed/exchangeable and mobilizable form (van der Heijden et al 2015; van der Heijden et al 2017), (ii) trees may remobilize nutrient reservoirs from dead/dying tissues, a process known as plant internal cycling (Lévy et al., 1996; Meerts, 2002). Some studies have also shown that trees may compensate for low nutrient availability in the soil and thus sustain their growth by intensifying the plant internal cycling (e.g., Weatherall et al., 2006; Weatherall et al., 2006b, 2006a, Achat et al., 2018b).

The objective of this study was to identify and quantify how the reduction of nutrient availability in the soil, resulting from the removal of harvest residues and litter, affects tree growth, wood density and nutrient concentration in tree stems as well as the remobilization of nutrients stored in the pith of the stem wood. For this purpose, we studied two sites belonging to the MOS (Manipulation de la Matière Organiques des Sols) network (Akroume et al., 2016), which was established in 2013 to study the impact of removing harvest residues on ecosystem functioning, including the effects on soil biodiversity (Elie et al., 2018, Maillard et al. 2019). We analyzed the oldest (close to pith) and the newly formed (close to bark) tree rings in increment cores extracted from European beech (Fagus sy/vatica) and oak (Q. petraea, Q. robur) trees at both sites.

The hypothesis we have formulated, on how trees respond to soil fertility loss due to intensive harvest residue and litter removal are (a) tree size (height and diameter) decreases (b) the density of newly formed tree rings decreases (we expect a decline in ring-width, which is expected to further affect wood density, in both species) and (c) internal reservoirs of nutrients stored in the tree stem are remobilized to compensate the decreased availability of nutrients in the soil. 


\section{Materials And Methods}

Study sites

This study was carried out in north-eastern France (Champenoux and Darney) at two experimental sites, which belong to the experimental plot network named MOS (Manipulation de la Matière Organiques des Sols: https://www6.inrae.fr/in-sylva-france/Services/IN-Situ/Reseau-MOS-Manipulation-de-la-matiereorganique-du-sol). The forest stand at the site in Champenoux is dominated by oak (Quercus petraea L. and Quercus roburL.) mixed with hornbeam (Carpinus betulus). In contrast, the Darney site is mainly composed of European beech (Fagus sylvatica L.). The stands at both sites were naturally regenerated. The average age of the stands was $37(s d=7)$ years for the oak trees and $31(s d=8)$ years for the beech trees (table 1). Prior to the establishment of the experimental plots, standard forest management practices were carried out at both sites following local management plans: selective thinnings occurred every 7 years and the harvested stems were extracted from the stands leaving harvest residues on site. The different treatment plots were installed just after a thinning in November 2013 in Champenoux and January 2014 in Darney. Since then, no thinning operations have been carried out. The full description of the experimental design can be found in Akroume et al., 2016.

\section{Experimental design and treatments}

In this study, we focused on two contrasted treatments: (1) conventional forest management (control treatment), in which the logging residues (branches under $7 \mathrm{~cm}$ diameter) and litter were kept on the forest floor after harvesting and (2) RHRL (Removing Harvest Residues and Litter), every year the fallen tree residues and litter were removed using a leaf blower or manually leaving a bare forest soil surface. Although, complete removal of litter is not a common practice, but an experimental one, its purpose is to achieve a nutrient and carbon loss equivalent to repeated intensive harvesting and biomass exportation, only over a shorter time period. Each experimental site covered 2 ha and treatment plots (area $40 \mathrm{~m} \times 40$ $\mathrm{m}$ each) were assigned randomly in a bloc design. Blocs and plots were defined and the inter-plot homogeneity was checked using near- and mid-infrared spectroscopy in soil and litter samples. (i.e., that there were no statistically significant differences between plots and blocs before the treatments were applied). At each site, treatment plots were replicated three times, leading to 6 studied plots ( 3 blocs $\times 2$ treatment plots) per site and 12 studied plots in total. Sampling and measurements were carried out within a $30 \mathrm{~m} \times 30 \mathrm{~m}$ subplot in each of the treatment plots to avoid potential border effects.

Soil Information

The soil at both Darney and Champenoux was described as Dystric Cambisols according to the World Reference Base for Soil (FAO and IUSS, 2015). For all stands, the humus form was a mesomull (Jabiol et al., 2009), with clay loam and sandy clay loam texture in the respective sites (table 1). Generically, soil fertility in the site Darney was comparatively poorer than site Champenoux (Akroume et al., 2016). To evaluate the treatment effect, i.e., RHRL on soil properties, a study was conducted by Maillard et al. 2019 at site Darney in beech trees after 3 years of the establishment of experimental plots. The study found 
that, the total soil $\mathrm{N}$, soil organic $\mathrm{C}$, soil organic matter (SOM) and $\mathrm{pH}$ were not impacted by removing harvest residuals, but removing harvest residuals significantly affected the other soil parameters measured in the $0-5 \mathrm{~cm}$ soil layer (Fig. 1), leading to an average decrease of available P concentration $(-30 \%), C E C(-12 \%)$ and $\mathrm{C} / \mathrm{N}(-8 \%)$ in the RHRL plots compared with the control plots. The study also found a significant drastic effect of removing harvest materials upon the microbial metabolic profiles and enzymatic activities in both $0-5 \mathrm{~cm}$ and $5-10 \mathrm{~cm}$ soil layers.

\section{Tree sampling}

Tree diameter at breast height $(1.3 \mathrm{~m})$ was measured for all the trees inside the $30 \mathrm{~m} \times 30 \mathrm{~m}$ subplots with a diameter tape (12 plots, 3118 trees in total). Trees were selected randomly for height measurement based on $5 \mathrm{~cm}^{2}$-interval basal area classes. The height of approximately 35 trees per plot (452 trees in total) were then measured using a vertex (brand: Haglöf-Sweden, product code: 15-105-1008).

Increment cores of $4.3 \mathrm{~mm}$ diameter were collected at breast height from trees using a gasoline-driven increment borer. To avoid heterogeneity between treatments, the sampled trees were selected based on their diameter distribution (Fig. 2). At the Champenoux site, 10 oak tree increment cores ( 5 from dominant trees and 5 from suppressed trees) were collected from each plot, leading to 30 cores per treatment, whereas 15 beech increment cores were collected from each plot at the Darney site (10 dominant and 5 suppressed, leading to 45 cores per treatment). Cores from both dominant and supressed trees were taken, to assess the treatment effect according to the tree social classes. Sample chemical analysis required a minimum core length of $5 \mathrm{~cm}$. For trees with a diameter less than $10 \mathrm{~cm}$, the increment borer crossed the pith point. The average length of the increment cores was $10.6 \mathrm{~cm}(\mathrm{sd}=4 \mathrm{~cm})$ for the beech trees, and $9.5 \mathrm{~cm}(\mathrm{sd}=3 \mathrm{~cm})$ collected for the oak trees. The samples were stored in honeycomb polycarbonate panels immediately after extraction for further ring width, wood density, and nutrient analysis.

Ring width, wood density and nutrients measurement

The honeycomb polycarbonate panel plates were scanned (device: printer Toshiba e-studio 2518A; resolution: $600 \times 600 \mathrm{dpi}$ ) immediately after extraction to obtain an image (dimension: $5672 \times 2953$ pixels) of the green core length. The samples were oven-dried for 24 hours at $103^{\circ} \mathrm{C}$ and scanned again. The length from the pith to the bark of the oven-dried core images was measured using ImageJ software. We repeated the measurement on the green core images in case the pith location was difficult to identify in the images of the oven-dried samples, and shrinkage was taken into account. The shrinkage was calculated from the images, in percentage, as the difference between the green core length and the ovendried length of a full-length core, over the green length. In addition, the number of rings from the pith to the bark in the oven dried image was counted via microscopy to determine the tree age in number of years.

To assess treatment effects on tree ring width, nutrient content and wood density between the near pith and near bark area, we cut a $2.5 \mathrm{~cm}$ long sample from both ends of each core (Saint-André et al. 2002). 
This length was selected based on preliminary tests and to ensure that a minimum of $160 \mathrm{mg}$ of wood powder was obtained after crushing the samples. In trees $<10 \mathrm{~cm}$ diameter, the near pith samples were extracted keeping the pith location at the middle point. There was a total of 300 tree core subsamples (150 trees). The number of rings was counted for each tree core subsample to determine average ring widths near the pith and near the bark. The wood density $\left(\mathrm{kg} / \mathrm{m}^{3}\right)$ of the subsamples was measured for the whole core and for the 300 subsamples based on the oven-dried cores using the Xylotech platform, INRAE, Champenoux, with a medical X-ray scanner (model: GE BrightSpeed Excel). The polycarbonate plates (each containing 15 cores) were assembled by means of an adhesive tape to form packages of 17 plates. Six packages were passed together through the medical CT scanner following the specification made in Freyburger et al., 2009. For each package of 17 plates the X-ray scanner software produces about $400 \mathrm{CT}$ images $(512 \times 512$ pixels each), with a slice thickness of $0.625 \mathrm{~mm}$. A specific software was developed in order to detect automatically individual alveolar cells in a plate, containing the wood cores and to compute the wood density of each sample (Jacquin et al., 2017). Detailed methodology and specifications of the scan options and image properties are described within the XyloDensMap project (Leban et al. 2017, Jacquin et al 2017, 2019).

The subsamples were then digested using an Anton Paar Microwave Reaction System MultiWave 3000 with nitric acid, and the analysis of the major elements- $\mathrm{Al}, \mathrm{Ca}, \mathrm{Fe}, \mathrm{K}, \mathrm{Mg}, \mathrm{Mn}, \mathrm{Na}$ and $\mathrm{S}$ was carried out by inductively coupled plasma atomic emission spectrometry (Agilent Technologies, 700 series ICP EOS) after digestion. P could not be assessed in our study, as the concentration in wood recorded was below the detection limits.

\section{Data analysis}

Minimum (Min), maximum (Max), mean, median, and standard deviation (SD), values were calculated for both explanatory and dependant variables. Tree basal area $\left(\mathrm{m}^{2} / \mathrm{ha}\right)$ and stem density (number of stems / ha) were calculated for each bloc, and site for both species. Treatment effect on tree height and diameter were assessed with boxplots and height-diameter curves for each species. To determine the treatment effect on the properties of near bark and near pith samples at each site, generalised linear regression models (GLMs) were performed using R software (R core team, 2017) for the ring widths, wood densities and nutrient concentrations. Because the study focuses on harvest residues export, treatment effects were always considered a fixed variable in all models. Goodness of fit of the models was assessed with the $R^{2}$ and $R M S E$ indicators. The final selection of the model with the best fit was made using Akaike information criterion (AIC), based on maximum likelihood; the lower the value is, the better the model fit. The variation explained by each significant parameter in the selected models was calculated from their coefficient values.

\section{Results}

Effect on tree growth 
For the height and diameter, we found no RHRL effect for either the beech trees at the Darney site or the oak trees at the Champenoux site (Fig. 3). For the beech trees at the Darney site, the growth ring width in the RHRL plot was significantly $(p=0.1)$ and on average $0.18 \mathrm{~mm}$ smaller ( $14 \%$ relative decrease) in the newly formed rings compared to the control plots (Fig. 4). We also observed a significant decrease (17.37 $\mathrm{kg} / \mathrm{m}^{\wedge} 3$ or $3 \%$ relative decrease, $\mathrm{p}=0.05$ ) in wood density between RHRL and control plots (Fig. 4 ).

For the oak trees at the Champenoux site, growth ring width in the RHRL plot was also slightly smaller in the newly formed rings compared to the control plot but this difference was not statistically significant (Fig. 4). There was no treatment effect on wood density in oak trees. However, for near bark samples, the growth ring width was statistically significant $(p=0.01)$ in the generalized linear model predicting wood density (table 2). Among the total variation of $25 \%$ explained by the model, over $15 \%$ came from ring width alone.

Effect on stem wood nutrients

In the beech trees of the Darney site, the concentrations of $\mathrm{Mg}, \mathrm{Na}$ and $\mathrm{S}$ in the near bark area were significantly lower in the RHRL plot, by $44 \%, 76 \%$ and $56 \%$, respectively; the concentrations of $\mathrm{K}$ and $\mathrm{Ca}$ were also lower, but non significantly. Al, Mn and Fe concentrations were significantly higher, by $65 \%, 26 \%$ and $137 \%$, respectively.

In the oak trees of the Champenoux site, the $\mathrm{K}, \mathrm{Ca}, \mathrm{Mg}, \mathrm{Na}$ and $\mathrm{S}$ concentrations in the near bark area were significantly lower in the RHRL plot, by $20 \%, 25 \%, 41 \%, 48 \%, 41 \%$ and $16 \%$, respectively. Fe, Mn or Al concentrations were also lower in the RHRL plot but the differences were not statistically significant.

In the near pith area in the RHRL plots, the concentrations of $\mathrm{K}, \mathrm{Mg}, \mathrm{Na}, \mathrm{Al}$ and $\mathrm{S}$ were significantly lower than the Control plots in the beech trees (Ca was lower, but non-significant) and the concentrations of $\mathrm{K}$, $\mathrm{Ca}, \mathrm{Na}$ and Fe were significantly lower in the oak trees ( $\mathrm{Mg}, \mathrm{S}$ and $\mathrm{Al}$ concentrations were lower, but nonsignificant) (table 3.2).

The relative decrease of nutrient concentration (Control - RHRL) / Control), calculated from the mean values, revealed, in the beech trees the relative decrease (in percentage) of near pith concentrations was $370 \%, 8 \%$ and $47 \%$, for $\mathrm{K}, \mathrm{Mg}$ and Ca respectively, and was greater than that of near bark tissues (Fig. $5 \mathrm{a}$ ), indicating relocation of nutrients from pith tissues in the RHRL plots. This observation was not repeated for oak (Fig. 5b). We also calculated the mean difference in the nutrient concentration between the near bark and near pith tissues ('near bark' minus 'near pith') in respect to treatment and species, and for beech trees, we found this difference to be significantly greater in $\mathrm{K}(<0.001)$ and in $\mathrm{Mg}$ (but non-significant), in the RHRL plots compared to the control (table 3.2).

Only for the oak trees in the Chamepnoux site, including the diameter improve the goodness of fit of the model predicting the treatment effect on nutrient concentrations in the near bark area. We found a significant positive response from diameter to explain nutrient concentrations regarding all the elements analysed except for $\mathrm{Ca}$ and $\mathrm{Al}$. The response from diameter were highest for $\mathrm{K}$ and $\mathrm{S}$ accounting 
approximately $82 \%$ and $63 \%$ of the total variation explained by full respective models (Table 3.2; Appendix B.1).

\section{Discussion}

Tree growth and wood density

In our study, RHRL treatment did not affect the tree dimensions (height or diameter) after 5 years of treatment. Nevertheless, we showed that the RHRL treatment decreased tree growth (newly formed rings) in the beech plots. A number of studies have also reported that increasing biomass exportations from forest stands resulted in a decrease in the growth rate of trees (see Achat et al., 2015). However, these studies reported growth rates of very young trees after a clear-cut, while our study focused on 30-year-old trees. This effect is most likely due to the decreased availability of nutrients in the soil. For the Darney site, Maillard et al. (2019) showed that the RHRL treatment significantly decreased the contents in soil nutrients and the cation exchange capacity. Other studies have reported that depletion or enrichment of soil nutrients conveys a direct relationship with tree ring width and wood density, in oak (e.g., Bergès et al., 2008; Kint et al., 2012; Ponton et al., 2019) and beech (e.g., Elhani et al., 2005) trees.

In our study, the RHRL treatment decreased ring width and wood density in oak trees but non-significantly. In general, tree growth of diffuse porous species such as beech is found to be more responsive to stress than ring porous species such as oak (Meyer et al., 2020). This may explain the differences observed in this study between the beech stands at the Darney site and the oak stands trees at the Champenoux site. This difference could also be explained by the differences in soil nutrient availability between the two sites. The availability of soil nutrients at the Darney site was lower than that at the Champenoux site. This may have led to more acute effects at the Darney site.

Wood density variability is found to be less affected by radial growth components in the diffuse porous species, compared to ring porous species (Bouriaud et al., 2004; Diaconu et al., 2016). Along with other components such as- cambial age and climatic variables, ecological factors (e.g., soil fertility nutrients etc.) are also found to explain variability in radial growth and wood density. However, in the related studies, factors such as climate, water and nutrients were not distinguished (Bergès et al., 2008), and site condition variability was largely not accounted for; for instance, in most cases, extreme site conditions were not sampled or were undersampled (e.g., Polge and Keller, 1973; Becker, 1979; Guilley et al., 2004). In our study, for the beech trees, the ring width in the treatment plots (i.e., RHRL) explains less than $1 \%$ of the wood density reduction in the newly formed rings; to the remaining variation (of the $2.56 \%$ observed) comes from the treatment itself (after the ring width effect is removed). There might be a modification of the cell properties in addition to the reduction in the ring width. However, additional anatomical studies are required to verify this hypothesis. This could not be conducted in our study because the subsamples were milled to analyse their nutrient content. It is also likely that a 5-years period of intensive harvest might not be long enough to observe the effect and distinguish the variability in wood density among 
species; however, preliminary effects were seen in beech at the Darney site, suggesting that this species may be used as a sentinel.

\section{Nutrient Status}

Two particular phenomena about the dynamics of nutrients as a consequence of removing harvest materials could be identified from our study: (i) there was a sharp decrease in nutrients for both the near bark and near pith regions in the treatment plots and (ii) the results suggest that certain nutrients were translocated from the near pith region to the near bark region in the beech trees to compensate for the lower availability of nutrients in the soil.

The loss of nutrients in the soil as a consequence of removing harvest materials from forests had been reported in many parts of the world. Tamminen et al. (2012), Brandtberg \& Olsson (2012), Kaarakka et al. (2014) and Vangansbeke et al. (2015) found depletion of one or multiple soil base cations (K, Ca, and $\mathrm{Mg}$ ) due to WTH in the Scandinavian trial studies. The same was also reported in North America (e.g., Ponder et al., 2012-from the North American long-term soil productivity (LTSP) network; Johnson et al., 2015; Johnson et al., 2016) and also from the tropical studies (see workshop proceedings from- Nambiar, 2008; Kumaraswamy et al., 2014). The concentration of nutrients in the stem heartwood can act as an indicator of the nutrient status in the soil (Lévy et al., 1996). We may assume that the loss of nutrients from trees in response to our treatment, was a consequence of losing nutrients from the soil, due to removing harvest residues. Maillard et al., 2019 (see subsection 2.2) conducted a parallel study on the same experimental site and found significant loss of soil nutrients and cation exchange capacity (CEC) in treatment plots at the Darney site. There were few/no cases in existing literature that studied the harvest removal effects on wood chemistry and nutrient translocation, but for both species, the wood nutrient values reported in our study were closer to those, where trees were growing in moderate to poor soil fertility $($ Table 4,5$)$.

In the RHRL plots, the relative decrease of near pith concentrations of $\mathrm{K}$ was above threefold higher than that of near bark tissues in beech trees. For $\mathrm{Mg}$ and $\mathrm{Ca}$, the relative decrease was also comparatively higher by $8 \%$ and $47 \%$ respectively. Besides, the difference in nutrient concentration ('near bark' minus 'near pith') was also significantly greater for $\mathrm{K}(\mathrm{p}<0.001)$ and for Mg (non-significant) in RHRL plots compared to the control plots. This trend indicates that these elements may have been internally translocated from the near pith tissues to the near bark tissues, probably to compensate for the nutrient loss, as described by Meerts (2002). The difference was not significant for $\mathrm{Mg}$, with a $54 \%$ proportional increase computed from the mean values. However, the internal compensation might not be as efficient for $\mathrm{Mg}$ as it is for $\mathrm{K}$, and $\mathrm{Mg}$ was still significantly lower in the near bark samples from the RHRL plot than it is in the samples from the control plots. However, our study supports the hypothesis stated by Penninckx et al. (2001) that the efficiency of the resorption of $\mathrm{Mg}$ is higher in sites with the lowest availability, as a possible mechanism to compensate the deficit from soil resources. Calcium, which is less mobile than Mg or K in trees (Mc Laughlin and Wimmer 1999, Lautner and Fromm, 2010), had a decreasing trend regarding treatment and also for the abovementioned difference value. Ca is found to be 
the least translocated element in trees, if not translocated at all (e.g., Colin-Belgrand et al., 1996; Fife et al., 2008) and often reported to be immobilized in great portion in the tree bark and stem wood tissue (Ferguson, 1979; Katainen and Valtonen, 1985). However, part of the Ca in aboveground biomass may be stored in an exchangeable/adsorbed and mobilizable form (van der Heijden et al 2015; van der Heijden et al 2017), Overall, in our study, the behaviour of Mg and Ca were similar in the RHRL plots in respect to remobilization from the near pith tissues. The Sulphur is found to be extensively lost from both the near bark area (55\%) and near pith area (45\%) in the beech trees and from the near bark area (41\%) in the oak trees. The forest floor is recognised as the major pool of $S$ available to trees (Cronan et al., 1978; Yanai, 1998), and the availability of $S$ in a soluble form is highly correlated with fungi and bacterial interactions in forest soils (Strickland and Fitzgerald, 1978). Thus, the removal of soil litter as well as the significant reduction in topsoil enzymatic activities due to the removal of harvest residues (Maillard et al. 2019) can explain the extensive loss of $S$ in the treatment plots.

In the oak trees, the concentrations of $\mathrm{K}, \mathrm{Ca}, \mathrm{Mg}, \mathrm{Na}$ and $\mathrm{S}$ were significantly depleted in both the near bark and near pith tissues (except for $\mathrm{Mg}$ and $\mathrm{S}$ in the heartwood) in the treatment plots. While the concentrations of $\mathrm{K}, \mathrm{Ca}$, and $\mathrm{Mg}$ were found to be significantly higher in the near bark area than that in the near pith area, which can indicate potential nutrient translocation (Lévy et al., 1996; André and Ponette., 2003), but these trends were not significant of the treatment. In contrast to most existing literature (Peri et al., 2006; André et al., 2010; Peri et al., 2010), we found a positive effect of tree diameter on the nutrient concentration in the oak near bark zone, but this could be because our stands are much younger than those assessed in published studies. Colin-Belgrand et al. (1996) found the same effect on stemwood in relatively young chestnut trees.

After 3 years of carrying out treatments in the same experimental plots as those used in our study, Maillard et al.(2019), did not find any change in the soil pH of the treatment plots, but the CEC of the soil was significantly decreased. At present, after 5 years, we have found a significant increase in the ratio of $\mathrm{Al} / \mathrm{Mg}(\mathrm{p}=0.001)$ in the treatment plots (Fig. 6), which potentially indicates increased acidity in the soil. (Lévy et al., 1999). The aberrant increase in the concentration of Fe in the treatment plots may also be related to high soil acidity (Meisch et al., 1986); however, this may be more likely due to instrument error related to the use of an increment borer to collect the stem wood samples (Augusto and Bert, 2005).

\section{Conclusion}

We found that removing harvest materials from intensively managed fuel wood stands did not affect tree diameter and height after five years, but the dendroecological analysis of the tree increment cores confirmed a significant reduction in radial growth and wood density in the newly formed rings of the beech trees. Nutrient concentrations were also reduced especially in the near bark tissues (and mostly for the base cations important to trees) in both species. In addition, the dendrochemical analysis has provided insight relating tree physiological adaptation (nutrient translocation) against poor site fertility and an indication of the acidity in the soil. 


\section{Abbreviations}

IPCC

Intergovernmental Panel on Climate Change; RHRL:Removing Harvest Residues and Litter; CEC:Cation Exchange Capacity; sd:standard deviation; SOM:Soil Organic Matter; WTH:Whole Tree Harvesting

\section{Declarations}

\section{Acknowledgments}

This research was carried out in the laboratory Biogeochimie des Ecosystèmes forestier (BEF), INRAE (Institut national de la recherche agronomique), Champenoux, FR. The research benefited from the unit's established experimental sites and the in situ and laboratory facilities for data and sample collection as well as for spectrometry and mineral analysis. We also benefited from the Silvatech platform (a shared platform between Silva and BEF, INRAE) for X-ray scanning of wood cores and wood density measurements by image analysis. Both units (BEF and Silva) are supported by the Labex ARBRE.

\section{Authors' contributions}

Jean-Michel LEBAN, Laurent SAINT-ANDRE and Bernhard ZELLER conceived and designed the experiment, edited and reviewed the manuscript draft. Sanjoy ROY contributed the study design, collected and prepared the data, analysed the data, prepared figures and tables, drafted the manuscript. Gregory van der HEIJDEN edited and validated the manuscript with critical comments and reviewed the manuscript draft. Arnaud REICHERT contributed the data collection and field visits. Marie-Christine GEHIN contributed the laboratory analysis. Philippe SANTENOISE contributed the data analysis. All authors checked and approved the final manuscript.

\section{Funding}

This work was supported within the XyloDensMap project, INRAE funded by the French Ministry of Agriculture under the convention $n^{\circ} \mathrm{A6} .01 / 2017$.

\section{Availability of data and materials}

The data set generated for the study area is available from the corresponding author on reasonable request.

\section{Declarations}

\section{Ethics approval and consent to participate}

Not applicable.

\section{Consent for publication}


Not applicable.

\section{Competing interests}

The authors declare that they have no competing interests.

\section{Author details}

${ }^{1}$ INRAE, UR1138, Biogéochimie des Ecosystèmes Forestiers, Champenoux, France, F-54280. ${ }^{2}$ IGN, Laboratoire de l'Inventaire Forestier, Nancy, France, F-54000

${ }^{3}$ INRAE, Silva, Champenoux, France, F-54280

\section{References}

1. Achat DL, Deleuze C, Landmann G et al (2015a) Quantifying consequences of removing harvesting residues on forest soils and tree growth - A meta-analysis. For Ecol Manage 348:124-141. https://doi.org/10.1016/j.foreco.2015.03.042

2. Achat DL, Fortin M, Landmann $\mathrm{G}$ et al (2015b) Forest soil carbon is threatened by intensive biomass harvesting. Sci Rep 5:1-10. https://doi.org/10.1038/srep15991

3. Achat DL, Pousse N, Nicolas M, Augusto L (2018) Nutrient remobilization in tree foliage as affected by soil nutrients and leaf life span. Ecol Monogr 88:408-428. https://doi.org/10.1002/ecm.1300

4. Akroume E, Zeller B, Buée $M$ et al (2016) Improving the design of long-term monitoring experiments in forests: a new method for the assessment of local soil variability by combining infrared spectroscopy and dendrometric data. Ann For Sci 73:1005-1013. https://doi.org/10.1007/s13595016-0572-3

5. André F, Jonard M, Ponette Q (2010) Biomass and nutrient content of sessile oak (Quercus petraea (Matt.) Liebl.) and beech (Fagus sylvatica L.) stem and branches in a mixed stand in southern Belgium. Science of The Total Environment 408:2285-2294. https://doi.org/10.1016/j.scitotenv.2010.02.040

6. André F, Ponette Q (2003) Comparison of biomass and nutrient content between oak (Quercus petraea) and hornbeam (Carpinus betulus) trees in a coppice-with-standards stand in Chimay (Belgium). Ann For Sci 60:489-502. https://doi.org/10.1051/forest:2003042

7. Augusto L, Bert D (2005) Estimating stemwood nutrient concentration with an increment borer: a potential source of error. Forestry 78(4):451-455. https://academic.oup.com/forestry/article/78/4/451/646083

8. Becker M, Claude RF, Schipfer R (1979) Une étude phyto-écologique sur les plateaux calcaires du Nord-Est (Massif de Haye-54). Ann Sci forest 36:93-124. https://doi.org/10.1051/forest/19790201

9. Bergès L, Nepveu G, Franc A (2008) Effects of ecological factors on radial growth and wood density components of sessile oak (Quercus petraea Liebl.) in Northern France. For Ecol Manage 255:567- 
579. https://doi.org/10.1016/j.foreco.2007.09.027

10. Bouriaud O, Bréda N, Le Moguédec G, Nepveu G (2004) Modelling variability of wood density in beech as affected by ring age, radial growth and climate. Trees 18:264-276.

https://doi.org/10.1007/s00468-003-0303-x

11. Brandtberg P-O, Olsson BA (2012) Changes in the effects of whole-tree harvesting on soil chemistry during 10years of stand development. For Ecol Manage 277:150-162.

https://doi.org/10.1016/j.foreco.2012.04.019

12. Castro VR, Chambi-Legoas $R$ et al (2020) The effect of soil nutrients and moisture during ontogeny on apparent wood density of Eucalyptus grandis. Scientific reports 10(1):1-9.

https://www.nature.com/articles/s41598-020-59559-2

13. Chave J, Coomes D, Jansen S et al (2009) Towards a worldwide wood economics spectrum. Ecol Lett 12:351-366. https://doi.org/10.1111/j.1461-0248.2009.01285.x

14. Clarke N, Kiær LP, Janne Kjønaas $O$ et al (2021) Effects of intensive biomass harvesting on forest soils in the Nordic countries and the UK: A meta-analysis. For Ecol Manage 482:118877. https://doi.org/10.1016/j.foreco.2020.118877

15. COLIN-BELGRAND M, RANGER J, BOUCHON J (1996) Internal Nutrient Translocation in Chestnut Tree Stemwood: III. Dynamics Across an Age Series of Castanea sativa (Miller). Ann Bot 78:729-740. https://doi.org/10.1006/anbo.1996.0183

16. Cronan CS, Reiners WA, Reynolds RC, Lang GE (1978) Forest floor leaching: contributions from mineral, organic, and carbonic acids in new hampshire subalpine forests. Science 200:309-311. https://doi.org/10.1126/science.200.4339.309-a

17. DeWalle DR, Swistock BR, Sayre RG, Sharpe WE (1991) Spatial Variations of Sapwood Chemistry with Soil Acidity in Appalachian Forests. J Environ Qual 20:486-491. https://doi.org/10.2134/jeq1991.00472425002000020024x

18. Diaconu D, Wassenberg M, Spiecker H (2016) Variability of European beech wood density as influenced by interactions between tree-ring growth and aspect. Forest Ecosystems 3:6. https://doi.org/10.1186/s40663-016-0065-8

19. Egnell G (2017) A review of Nordic trials studying effects of biomass harvest intensity on subsequent forest production. For Ecol Manage 383:27-36. https://doi.org/10.1016/j.foreco.2016.09.019

20. Elhani S, Guehl J-M, Nys C et al (2005) Impact of fertilization on tree-ring $\delta 15 \mathrm{~N}$ and $\delta 13 \mathrm{C}$ in beech stands: a retrospective analysis. Tree Physiol 25:1437-1446

21. https://doi.org/10.1093/treephys/25.11.1437

22. Elie $F$ (2018) Soil fauna as bioindicators of organic matter export in temperate forests. For Ecol Manage 429:549-557. https://doi.org/10.1016/j.foreco.2018.07.053

23. FAO (2014) World reference base for soil resources 2014: international soil classification system for naming soils and creating legends for soil maps. FAO, Rome 
24. Ferguson IB (1980) THE UPTAKE AND TRANSPORT OF CALCIUM IN THE FRUIT TREE. Acta Hortic 183-192. https://doi.org/10.17660/ActaHortic.1980.92.21

25. Fife DN, Nambiar EKS, Saur E (2008) Retranslocation of foliar nutrients in evergreen tree species planted in a Mediterranean environment. Tree Physiol 28:187-196.

https://doi.org/10.1093/treephys/28.2.187

26. Freyburger C, Longuetaud F, Mothe F et al (2009) Measuring wood density by means of X-ray computer tomography. Ann For Sci 66:804-804. https://doi.org/10.1051/forest/2009071

27. Guilley E, Hervé J-C, Nepveu G (2004) The influence of site quality, silviculture and region on wood density mixed model in Quercus petraea Liebl. For Ecol Manage 189:111-121.

https://doi.org/10.1016/j.foreco.2003.07.033

28. Helmisaari H-S, Hanssen K, Jacobson S et al (2011) Logging residue removal after thinning in Nordic boreal forests: Long-term impact on tree growth. For Ecol Manage 261:1919-1927. https://doi.org/10.1016/j.foreco.2011.02.015

29. Herbauts et al. Radial variations in cation exchange capacity and base saturation rate in the wood of pedunculate oak and European beech. https://cdnsciencepub.com/doi/10.1139/x02-097

30. Hume AM, Chen HYH, Taylor AR (2018) Intensive forest harvesting increases susceptibility of northern forest soils to carbon, nitrogen and phosphorus loss. J Appl Ecol 55:246-255. https://doi.org/10.1111/1365-2664.12942

31. IPCC 2006 (2006) In: Eggleston HS, Buendia L, Miwa K, Ngara T, Tanabe K (eds) IPCC Guidelines for National Green house Gas Inventories, prepared by the National Green-house Gas Inventories Programme, vol 4, Chap. 4: Forest Land, table Table 4.14. IGES, Japan

32. Jabiol B, Brêthes A, Brun J-J et al (2009) Typologie des formes d'humus forestières (sous climats tempérés). https://doi.org/10.13140/RG.2.1.2263.7287

33. Jacquin P, Longuetaud F, Leban J-M, Mothe F (2017) X-ray microdensitometry of wood: A review of existing principles and devices. Dendrochronologia 42:42-50.

https://doi.org/10.1016/j.dendro.2017.01.004

34. Jacquin P, Mothe F, Longuetaud F et al (2019) CarDen: A software for fast measurement of wood density on increment cores by CT scanning. Comput Electron Agric 156:606-617. https://doi.org/10.1016/j.compag.2018.12.008

35. Johnson DW, Trettin CC, Todd DE (2016) Changes in forest floor and soil nutrients in a mixed oak forest 33 years after stem only and whole-tree harvest. For Ecol Manage 361:56-68. https://doi.org/10.1016/j.foreco.2015.11.012

36. Johnson J, Aherne J, Cummins T (2015) Base cation budgets under residue removal in temperate maritime plantation forests. For Ecol Manage 343:144-156.

https://doi.org/10.1016/j.foreco.2015.01.022

37. Kaarakka L, Tamminen P, Saarsalmi A et al (2014) Effects of repeated whole-tree harvesting on soil properties and tree growth in a Norway spruce (Picea abies (L.) Karst.) stand. For Ecol Manage 313:180-187. https://doi.org/10.1016/j.foreco.2013.11.009 
38. Katainen HS, Valtonen E (1985) Nutrient retranslocation in relation to growth and senescence of Scots pine needles. Crop physiology of forest trees / compiled and edited by Peter MA Tigerstedt, Pasi Puttonen and Veikko Koski

39. Kerfriden B, Bontemps J-D, Leban J-M (2021) Variations in temperate forest stem biomass ratio along three environmental gradients are dominated by interspecific differences in wood density. Plant Ecol 222:289-303. https://doi.org/10.1007/s11258-020-01106-0

40. Kint $\mathrm{V}$, Vansteenkiste $\mathrm{D}$, Aertsen $\mathrm{W}$ et al (2012) Forest structure and soil fertility determine internal stem morphology of Pedunculate oak: a modelling approach using boosted regression trees. Eur $\mathrm{J}$ Forest Res 131:609-622. https://doi.org/10.1007/s10342-011-0535-z

41. Kumaraswamy S, Mendham DS, Grove TS et al (2014) Harvest residue effects on soil organic matter, nutrients and microbial biomass in eucalypt plantations in Kerala, India. For Ecol Manage 328:140149. https://doi.org/10.1016/j.foreco.2014.05.021

42. Lautner S, Fromm J (2010) Calcium-dependent physiological processes in trees. Plant Biol 12:268274. https://doi.org/10.1111/j.1438-8677.2009.00281.x

43. Leban J-M, Hervé J-C, Bontemps J-D et al (2017) Le projet XyloDensMap

44. https://doi.org/10.13140/RG.2.2.10112.74244

45. Lévy G, Bréchet C, Becker M (1996) Element analysis of tree rings in pedunculate oak heartwood: an indicator of historical trends in the soil chemistry, related to atmospheric deposition. Ann For Sci 53:685-696. https://doi.org/10.1051/forest:19960246

46. Maillard F, Leduc V, Bach $C$ et al (2019) Soil microbial functions are affected by organic matter removal in temperate deciduous forest. Soil Biol Biochem 133:28-36. https://doi.org/10.1016/j.soilbio.2019.02.015

47. McLAUGHLIN SB, Wimmer R (1999) Tansley Review No. 104. New Phytol 142:373-417. https://doi.org/10.1046/j.1469-8137.1999.00420.x

48. Meerts $P$ (2002) Mineral nutrient concentrations in sapwood and heartwood: a literature review. Ann For Sci 59:713-722. https://doi.org/10.1051/forest:2002059

49. Meisch H-U, Kessler M, Reinle W, Wagner A (1986) Distribution of metals in annual rings of the beech (Fagus sylvatica) as an expression of environmental changes. Experientia 42:537-542. https://doi.org/10.1007/BF01946693

50. Meyer BF, Buras A, Rammig A, Zang CS (2020) Higher susceptibility of beech to drought in comparison to oak. Dendrochronologia 64:125780. https://doi.org/10.1016/j.dendro.2020.125780

51. Nambiar EKS (ed) (2008) Site management and productivity in tropical plantation forests: Proceedings of Workshops in Piracicaba (Brazil) 22-26 November 2004 and Bogor (Indonesia) 6-9 November 2006. In: CIFOR. https://www.cifor.org/knowledge/publication/2517/

52. Park BB, Yanai RD (2009) Nutrient concentrations in roots, leaves and wood of seedling and mature sugar maple and American beech at two contrasting sites. For Ecol Manage 258:1153-1160. https://doi.org/10.1016/j.foreco.2009.06.003 
53. Penninckx V, Glineur S, Gruber W et al (2001) Radial variations in wood mineral element concentrations: a comparison of beech and pedunculate oak from the Belgian Ardennes. Ann For Sci 58:253-260. https://doi.org/10.1051/forest:2001124

54. Peri PL, Gargaglione V, Pastur GM (2006) Dynamics of above- and below-ground biomass and nutrient accumulation in an age sequence of Nothofagus antarctica forest of Southern Patagonia. For Ecol Manage 233:85-99. https://doi.org/10.1016/j.foreco.2006.06.009

55. Peri PL, Lasagno RG (2010) Biomass, carbon and nutrient storage for dominant grasses of cold temperate steppe grasslands in southern Patagonia, Argentina. J Arid Environ 74:23-34. https://doi.org/10.1016/j.jaridenv.2009.06.015

56. Phillips S, Flach B, Lieberz S et al (EU-28 Biofuels Annual EU Biofuels Annual 2018) 41

57. Polge H, Keller R (1973) Qualité du bois et largeur d'accroissements en forêt Tronçais. Ann Sci forest 30:91-125. https://doi.org/10.1051/forest/19730201

58. Ponder F, Fleming RL, Berch S et al (2012) Effects of organic matter removal, soil compaction and vegetation control on 10th year biomass and foliar nutrition: LTSP continent-wide comparisons. For Ecol Manage 278:35-54. https://doi.org/10.1016/j.foreco.2012.04.014

59. Ponton S, Bornot Y, Bréda N (2019) Soil fertilization transiently increases radial growth in sessile oaks but does not change their resilience to severe soil water deficit. For Ecol Manage 432:923-931. https://doi.org/10.1016/j.foreco.2018.10.027

60. Pyttel PL, Köhn M, Bauhus J (2015) Effects of different harvesting intensities on the macro nutrient pools in aged oak coppice forests. For Ecol Manage 349:94-105. https://doi.org/10.1016/j.foreco.2015.03.037

61. Saint-Andre L, Laclau J-P, Deleporte P et al (2002) A Generic Model to Describe the Dynamics of Nutrient Concentrations within Stemwood across an Age Series of a Eucalyptus Hybrid. Ann Bot 90:65-76. https://doi.org/10.1093/aob/mcf146

62. Saranpää $P$ (2003) Wood density and growth. Wood quality and its biological basis, 87-117

63. Sheppard PR, Casals i Tortras P, Gutiérrez Merino E (2001) Relationships between ring-width variation and soil nutrient availability at the tree scale. Tree-Ring Bulletin, 2001, vol. 57, num. 1, p. 105-113

64. Strickland TC, Fitzgerald JW (1984) Formation and mineralization of organic sulfur in forest soils. Biogeochemistry 1:79-95. https://doi.org/10.1007/BF02181122

65. Tamminen P, Saarsalmi A, Smolander A et al (2012) Effects of logging residue harvest in thinnings on amounts of soil carbon and nutrients in Scots pine and Norway spruce stands. For Ecol Manage 263:31-38. https://doi.org/10.1016/j.foreco.2011.09.015

66. Thiffault E, Hannam K, Paré D et al (2011) Effects of forest biomass harvesting on soil productivity in boreal and temperate forests - A review. Environmental Reviews 19:278-309. https://doi.org/10.1139/a11-009

67. van der Heijden G, Belyazid S, Dambrine E et al (2017) NutsFor a process-oriented model to simulate nutrient and isotope tracer cycling in forest ecosystems. Environ Model Softw 95:365-380. https://doi.org/10.1016/j.envsoft.2017.06.003 
68. van der Heijden G, Dambrine E, Pollier B et al (2015) Mg and Ca uptake by roots in relation to depth and allocation to aboveground tissues: results from an isotopic labeling study in a beech forest on base-poor soil. Biogeochemistry 122:375-393. https://doi.org/10.1007/s10533-014-0047-2

69. Vangansbeke P, De Schrijver A, De Frenne P et al (2015) Strong negative impacts of whole tree harvesting in pine stands on poor, sandy soils: A long-term nutrient budget modelling approach. For Ecol Manage 356:101-111. https://doi.org/10.1016/j.foreco.2015.07.028

70. Vanguelova E, Pitman R, Luiro J, Helmisaari H-S (2010) Long term effects of whole tree harvesting on soil carbon and nutrient sustainability in the UK. Biogeochemistry 101:43-59. https://doi.org/10.1007/s10533-010-9511-9

71. Wall A (2012) Risk analysis of effects of whole-tree harvesting on site productivity. For Ecol Manage 282:175-184. https://doi.org/10.1016/j.foreco.2012.07.012

72. Weatherall A, Proe MF, Craig J et al (2006a) Tracing N, K, Mg and Ca released from decomposing biomass to new tree growth. Part I: A model system simulating harvest residue decomposition on conventionally harvested clearfell sites. Biomass Bioenerg 30:1053-1059.

https://doi.org/10.1016/j.biombioe.2005.12.010

73. Weatherall A, Proe MF, Craig J et al (2006b) Tracing N, K, Mg and Ca released from decomposing biomass to new tree growth. Part II: A model system simulating root decomposition on clearfell sites. Biomass Bioenerg 30:1060-1066. https://doi.org/10.1016/j.biombioe.2005.12.016

74. Weatherall et al. Internal cycling of nitrogen, potassium and magnesium in young Sitka spruce | Tree Physiology | Oxford Academic. https://academic.oup.com/treephys/article/26/5/673/1690688

75. Yanai RD (1998) The effect of whole-tree harvest on phosphorus cycling in a northern hardwood forest. For Ecol Manage 104:281-295. https://doi.org/10.1016/S0378-1127(97)00256-9

\section{Tables}

Due to technical limitations, table 1 to 5 is only available as a download in the Supplemental Files section.

\section{Figures}




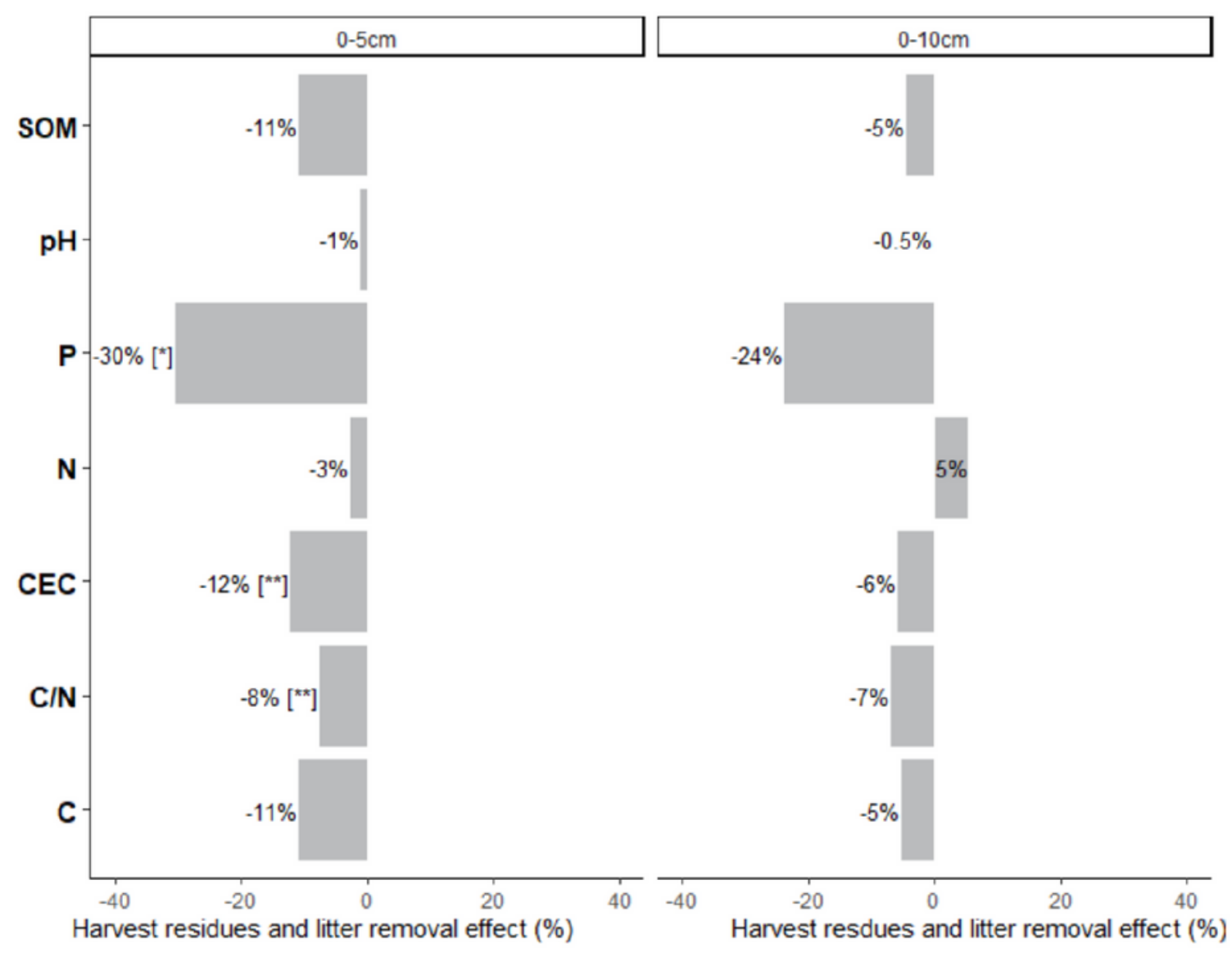

\section{Figure 1}

The effect of treatment i.e., RHRL-removing harvest residues and litter ((percentage change in the RHRL plots calculated with Control plots as denominator), after 3 years of the establishment of experimental plots, on the soil physical and chemical properties at the site Darney in two different soil layers $(0-5 \mathrm{~cm}$ and 5-10 cm). The value in the [ represents the P-value of the Pearson correlation. P-values, only for significant parameters are included ( $\left.{ }^{*} P \leq 0.05 ;{ }^{*} P \leq 0.01\right)$. Abbreviations: $N$, total nitrogen; $C$, total carbon; $\mathrm{SOM}$, soil organic matter; $\mathrm{P}$, available phosphorus; $\mathrm{CEC}$, cation exchange capacity; 

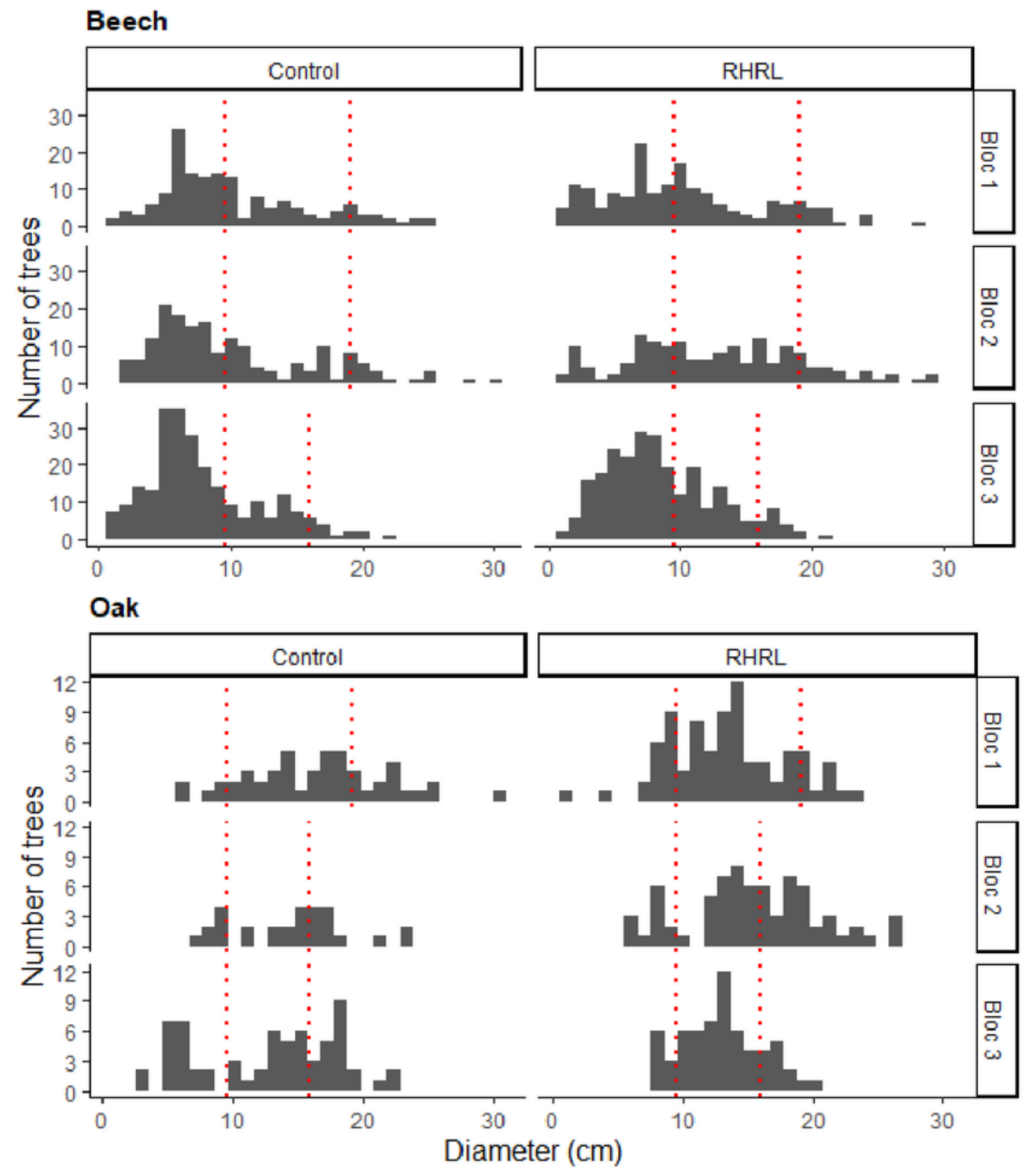

Figure 2

Distribution of tree densities to residue neutral blocs: trees with diameter outside the red lines were selected for sampling in each blocs. For the oak trees, the limits indicated by the red lines were $9.5 \mathrm{~cm} \geq$ selection $\geq 19.1 \mathrm{~cm} ; 9.5 \mathrm{~cm} \geq$ selection $\geq 15.9 \mathrm{~cm}$; and $9.5 \mathrm{~cm} \geq$ selection $\geq 15.9 \mathrm{~cm}$ for bloc 1 , bloc 2 and bloc 3 , respectively. For the beech trees, the limits were $9.5 \mathrm{~cm} \geq$ selection $\geq 19.1 \mathrm{~cm} ; 9.5 \mathrm{~cm} \geq$ selection $\geq 19.1 \mathrm{~cm}$; and $9.5 \mathrm{~cm} \geq$ selection $\geq 15.9 \mathrm{~cm}$. 


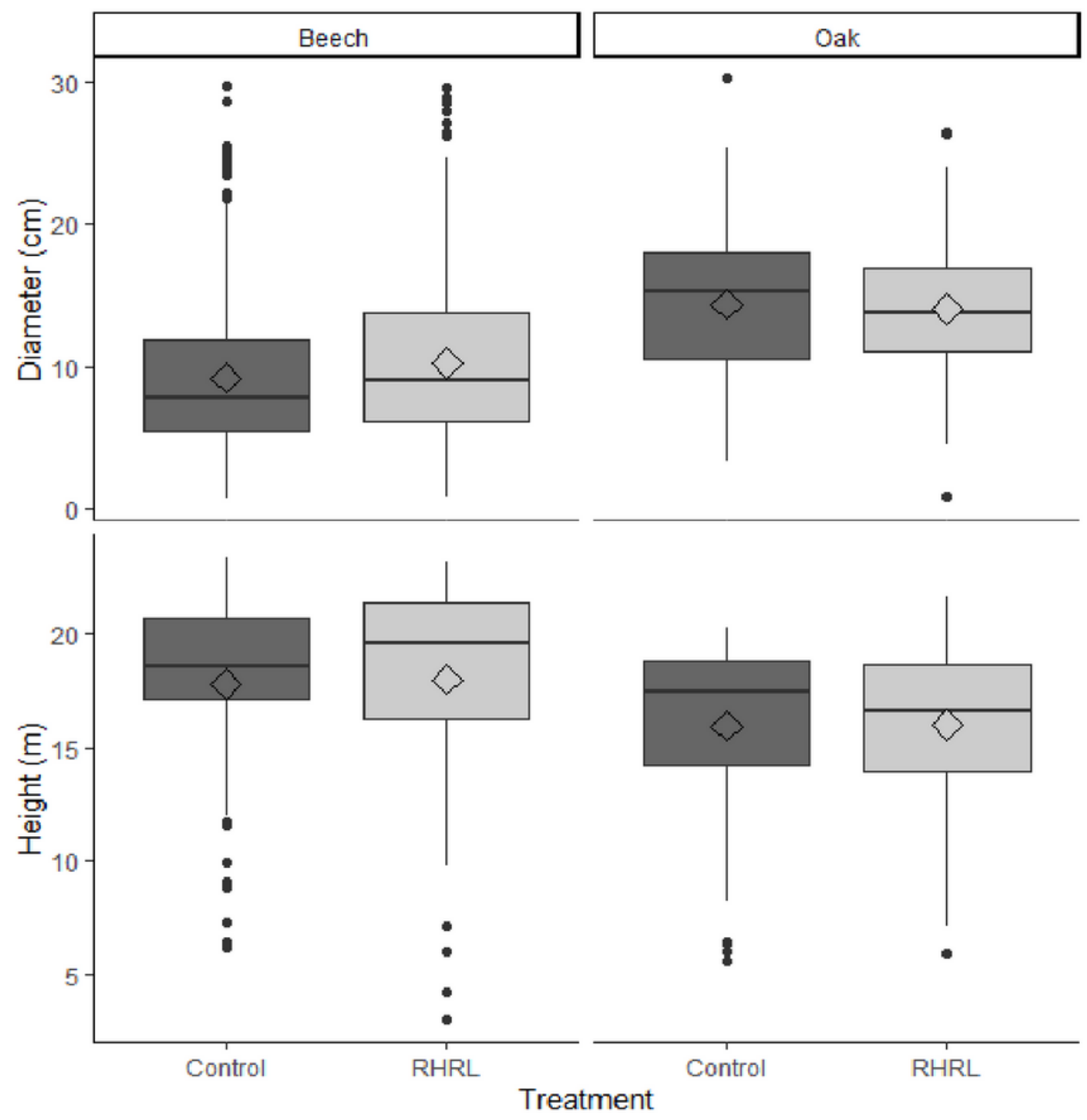

Figure 3

The effect of treatment (i.e., control-classical silviculture and RHRL-removing harvest residues and litter) on tree diameter at breast height $(\mathrm{cm})$ and height $(\mathrm{m})$ in the beech and oak trees. The effect is shown with mean indicators for the average value of diameter and height. 


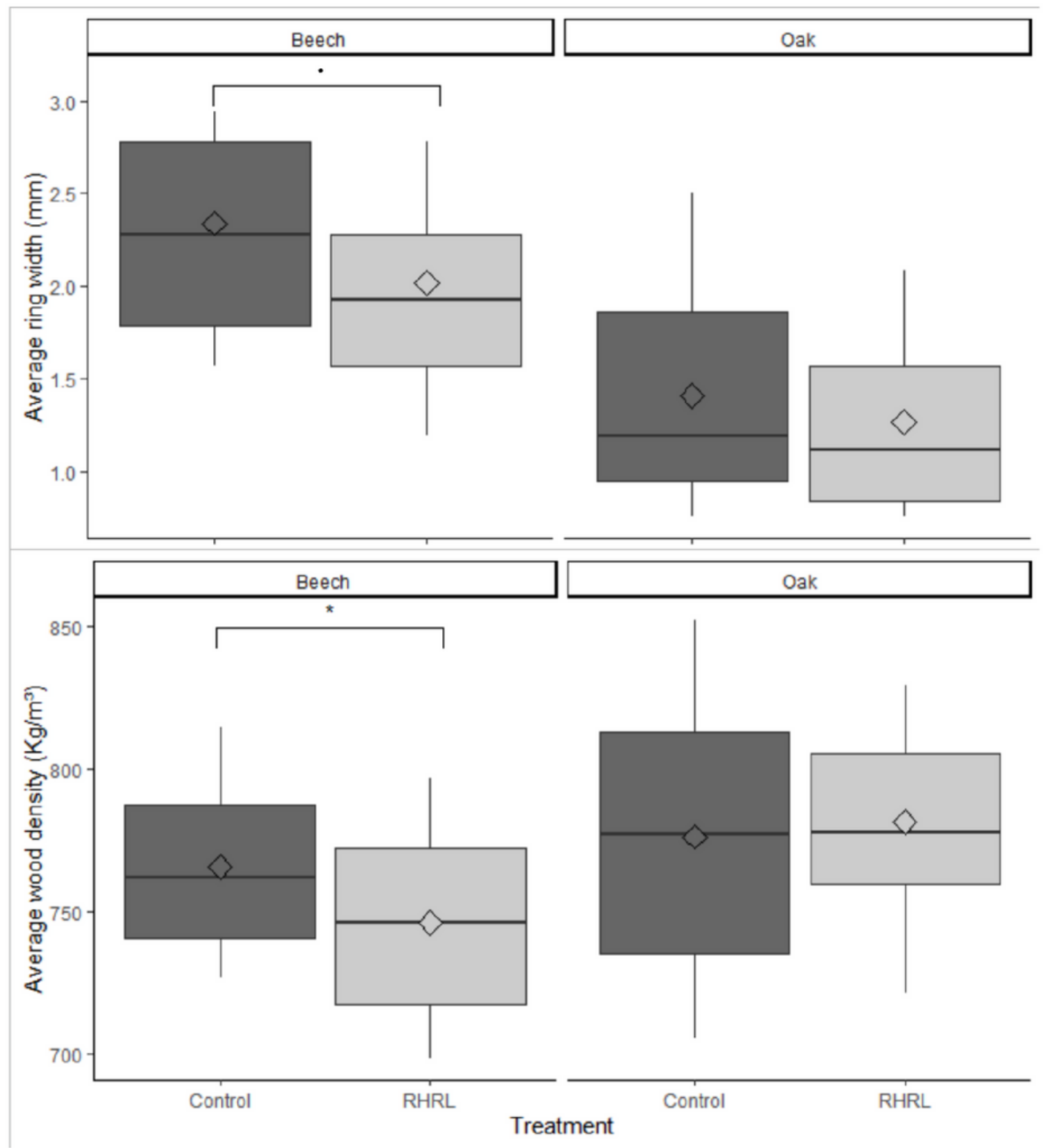

Figure 4

The effect of treatment (i.e., control-classical silviculture and RHRL-removing harvest residues and litter) on beech and oak tree ring width and wood density at the newly formed rings. The effect is shown over the population with mean indicators. The P-value of the Pearson correlation, only for significant parameters are indicated above the corresponding boxplots $(\mathbb{Q P} \leq 0.1 ; * P \leq 0.05 ; * \star P \leq 0.01)$ 
(a)

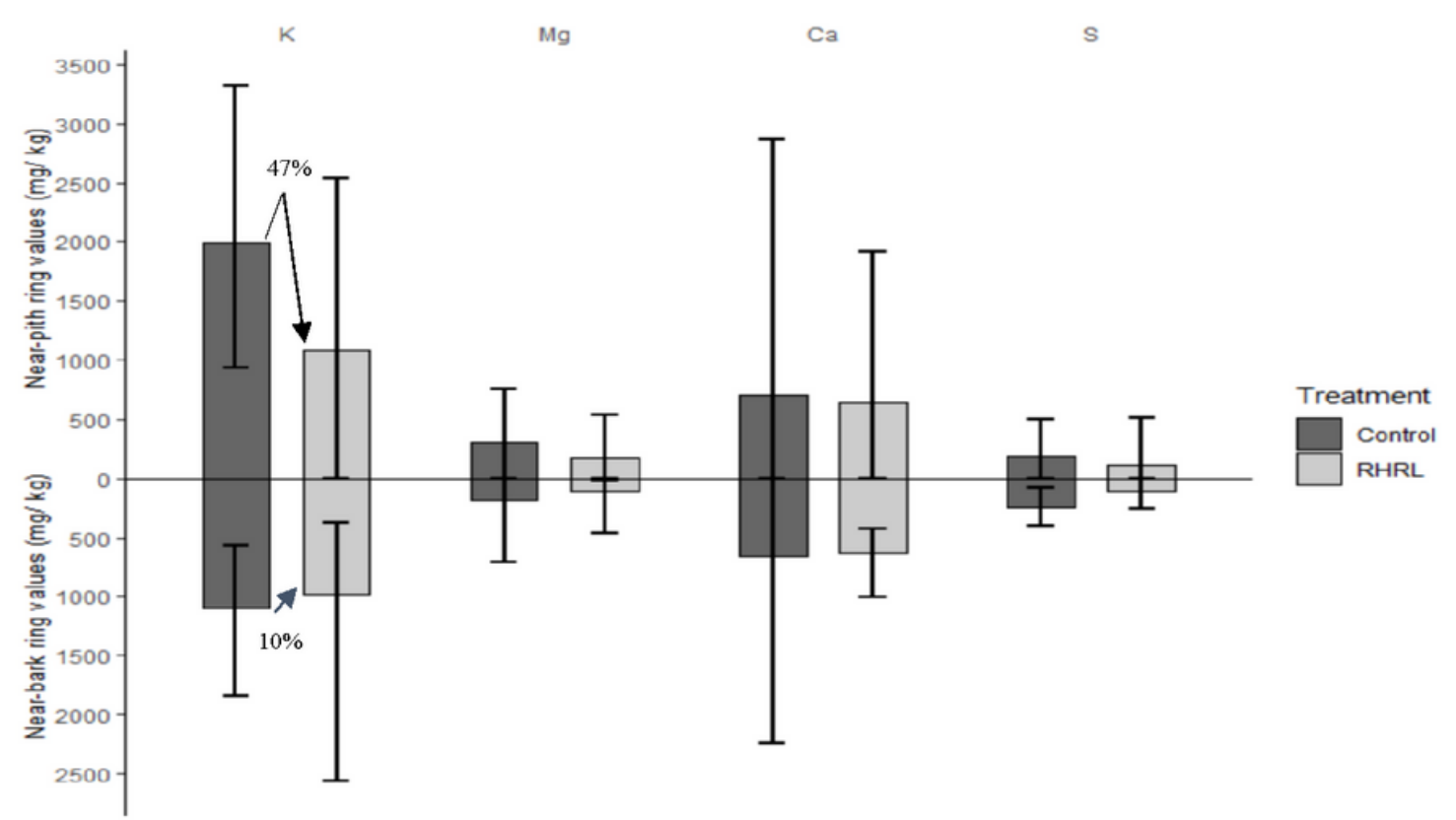

(b) oak

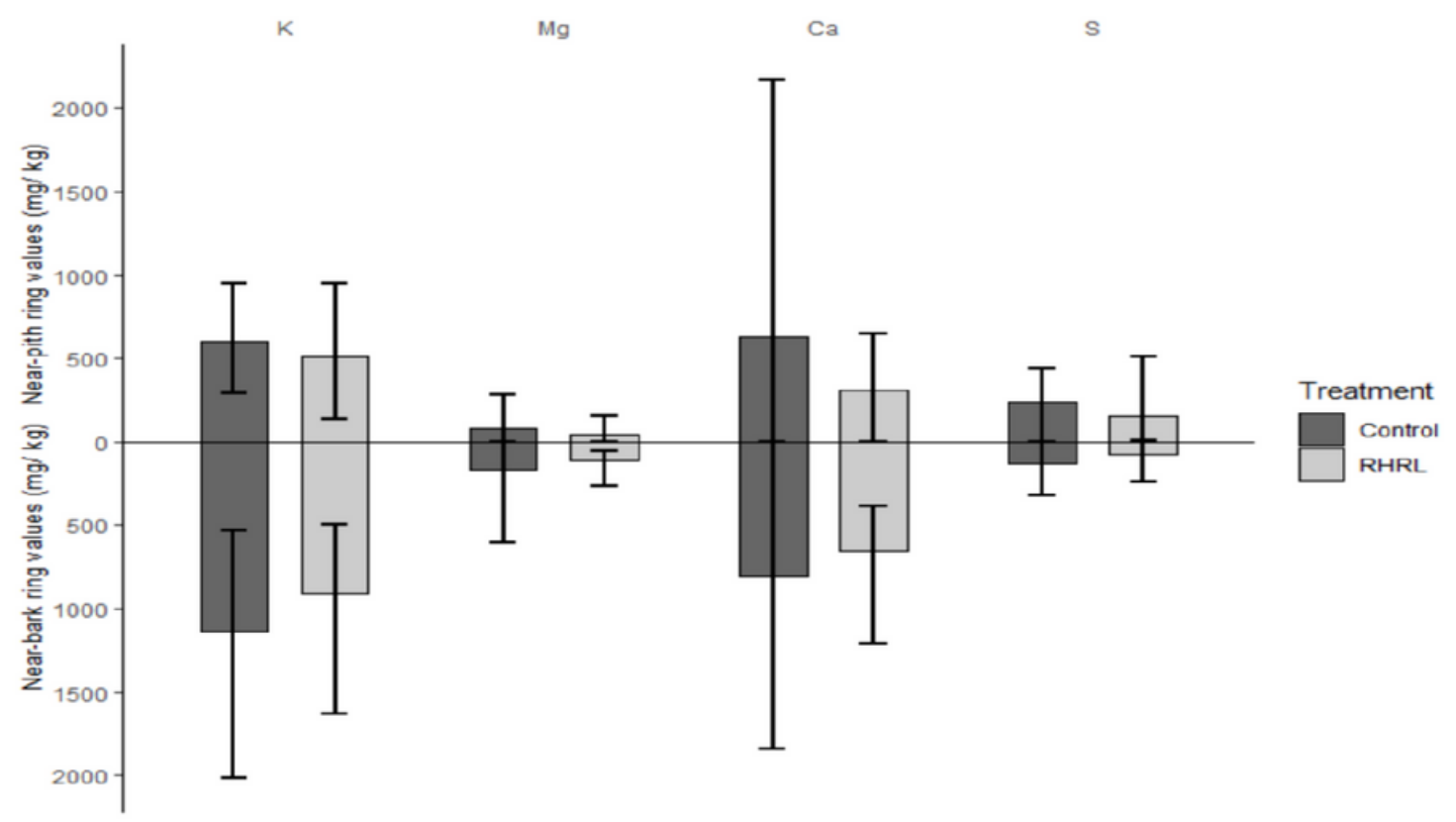

\section{Figure 5}

Nutrient concentration ( $\mathrm{mg} / \mathrm{kg}$ ) of $\mathrm{K}, \mathrm{Mg}, \mathrm{Ca}$, S occurring at the near pith and near bark tissues in (a) beech and (b) oak trees in respect to treatments, i.e., control-classical silviculture and RHRL -removing harvest residues and litter. The number in (\%) indicates relative decrease of the corresponding nutrient concentration (mean values) calculated as (Control-RHRL/Control) in the near pith and near bark zone.. 


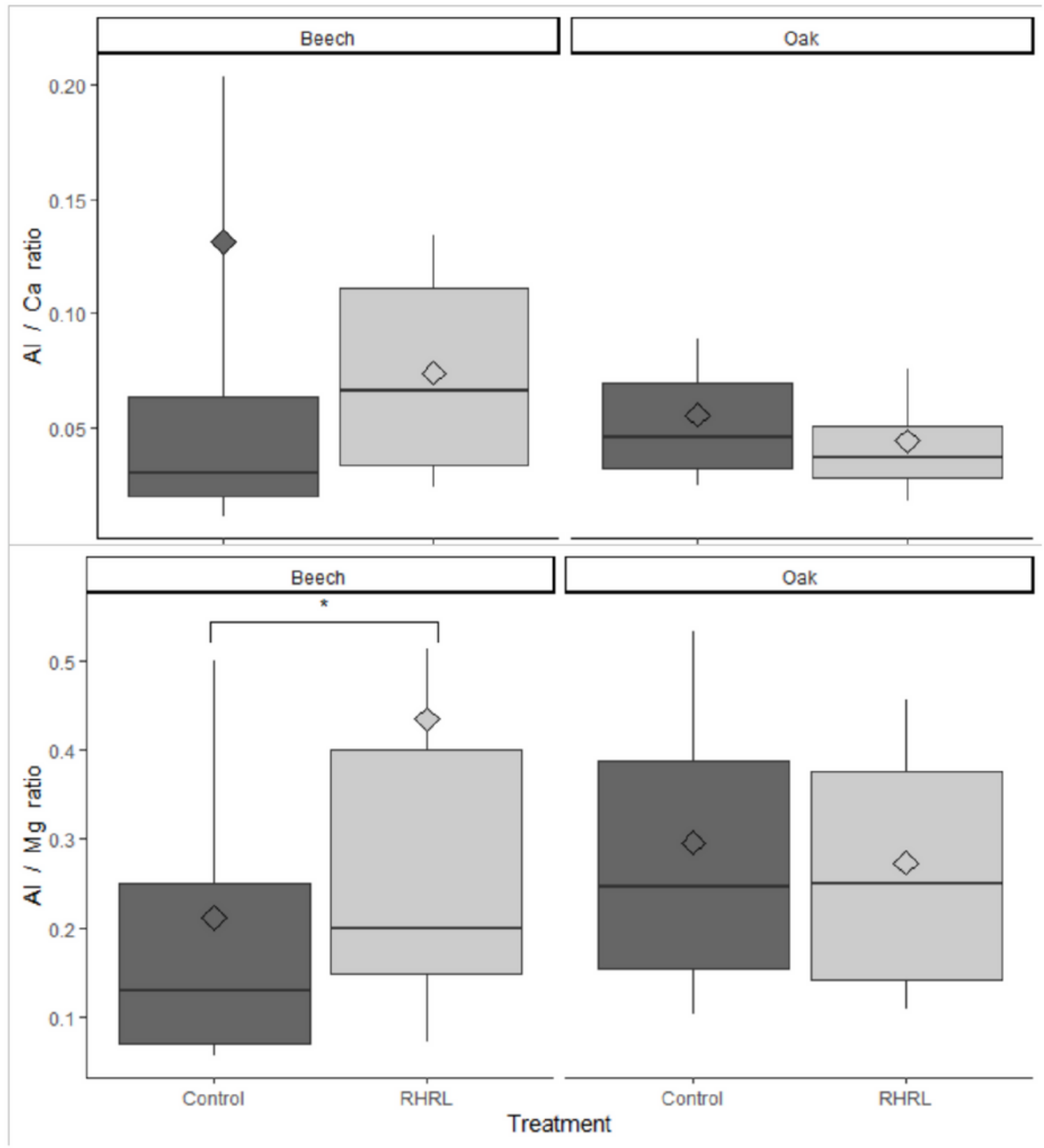

Figure 6

Indicator of soil acidity: $\mathrm{Al} / \mathrm{Ca}$ and $\mathrm{Al} / \mathrm{Mg}$ ratio in response to treatment (i.e., control-classical silviculture and RHRL - removing harvest residues and litter) for each species seen at the newly formed rings (near bark area), with mean indicators. The P-value of the Pearson correlation, only for significant parameters are indicated above the corresponding boxplots ( $\left.\mathbb{P} \leq 0.1 ;{ }^{*} \mathrm{P} \leq 0.05 ; * \star \mathrm{P} \leq 0.01\right)$

\section{Supplementary Files}

This is a list of supplementary files associated with this preprint. Click to download.

- Tables.pdf 
- Appendix.docx

Page 25/25 